\title{
The St. Louis Equation and Monthly Data
}

\author{
KEITH M. CARLSON
}

龆. $\mathrm{N}$ THE November 1968 issue of this Review, Leonall C. Andersen and Jerry L. Jordan published a study which reported results relating to the response of GNP to monetary and fiscal actions. ${ }^{2}$ Since then, there have been a number of articles which have analyzed and challenged these findings. ${ }^{3}$ Even though the final returns are probably not in yet, one has to be impressed with the way their results have withstood the criticism to which they have been subjected, ${ }^{3}$

The Andersen-Jordan article was concemed with the relative impact of monetary vs. fiscal actions, testing hypotheses relating to the magnitude, speed, and reliability of the response of GNP. Yet one of the more interesting implications of the St. Lotis equa tion (the reduced-form equation developed in their article) was that GNP responds quickly to monetary actions and that the adjustment is essentially completed in a year's time. This finding ran contrary to the prevailing view at that time, which was based, in part, on results obtained by large econometric models. For example, the Federal Reserve - MIT econometric model, a model specifically designed to quantify the effect of monetary actions on the economy, concluded

${ }^{1}$ Leonall C. Andersen and Jerry L. Jordan, "Monetary and Fiscal Actions: A Test of Their Relative Importance in Economic Stabilization," this Review (November 1968), pp. $11-24$.

Thepresentative examples are Frank deLeem and John Kalchbremer, "Monetary and Fiscal Actions: A r"est of Their Relative Importance in Fconomic Stabilization - Comment, this Review (April 1969), pp. 6-11; Richard G. Daves, "How Much Does Money Matter? A Look at Some Recent Evidence," Federal Reserve Bank of New York Monthly Review (Inme 1969), pp. 119-31; Franco Modigliani, "Monetary Policy and Consumption: Lirkages via Interest Rate and Wealth Effects in the FMP Model," Consumer Spending and Monetary Policy: The Linkages (Proceedings of a Monetay Conference held on Nantucket Island, Sponsored by Federal Reserve Bank of Boston, June 1971), pp. 59-74, Lawrence R. Klein, "Empirical Evidence on Fisea and Monetary Models", in James J. Diamond (ed.). Issues in Fiscal and Monetary Policy: The Eclectic Economist Views the Controoersy (DePaul University, 1971), pp. 35-50; and Alan S. Binder and Robert $M$. Solow, "Analytical Foundations of Fiscal Policy," The Economics of Public Finance (Washington, D.C.: The Brookings Institution, 1974), pp. 63-71.

3Professor Klein, for example, draws the following conclusion: "Hard econometric evidence points to the fact that large structural models stand up at least as well as small reduced form models." [Kleir, "Empirical Eyidence on Fiscal and Monetary Models," p. 49.$]$ "that monetary policy is ultimately quite powerful but that the lags are long."

There is an indication that some of the large econometric models have been modified in such a way that the impact of monetary actions now appears to be quicker than in earlier versions. For the most part, however, the St. Louis equation continues to stand apart from other models, showing that virtually all of the GNP response to changes in money occurs in about a year, though mention should be made of another model - the Laffer-Ranson model. ${ }^{6}$ Arthur Laffer and David Ranson not only found a quick response to monetary actions, but they concluded that monetary actions have an immediate and permanent effect on the level of GNP, rejecting the presence of any lags at all.

The purpose of this note is to report the results of estimating the St. Louis equation with monthly data and thereby sharpen our understanding of the ling in the effect of monetary and fiscal actions. The question being asked here is whether the St. Louis equation continues to hold when monthly data are used in the estimation. It is well-known among economic analysts that the use of data aggregated over time can introduce a bias in the results. ${ }^{\top}$

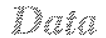

The data used to estimate the St. Louis equation consisted of changes in nominal GNP as the dependent variable and altemative measures of monetary and fiscal actions as the independent variable. For purposes of comparison here, only the specification

${ }_{4}$ Frank deLeeuw and Edward M. Gramlich, "The Federal Reserve - MIT Econometric Model, Federal Reserve Bulletin (January 1968), pp. 11-40.

"See Gary Fromm and L. R. Klein, "The NBER/NSF Model Comparison Seminar: An Analysis of Results," forthcoming in Amals of Economic and Social Measurement.

"Arthur B. Laffer and R. David Ranson, "A Formal Model of the Economy," The Joumal of Business (July 1971), pp. $247-60$.

7Yair Mundlak, "Aggregation Over Time in Distributed Lag Models," International Lconomic Review (May 1961), pp. 154-63, and William R. Bryan, "Bank Adiustments to Monetary Policy: Altemative Estimates of the Lage," Americon Economic Review (September 1967), pp. 855-64." 


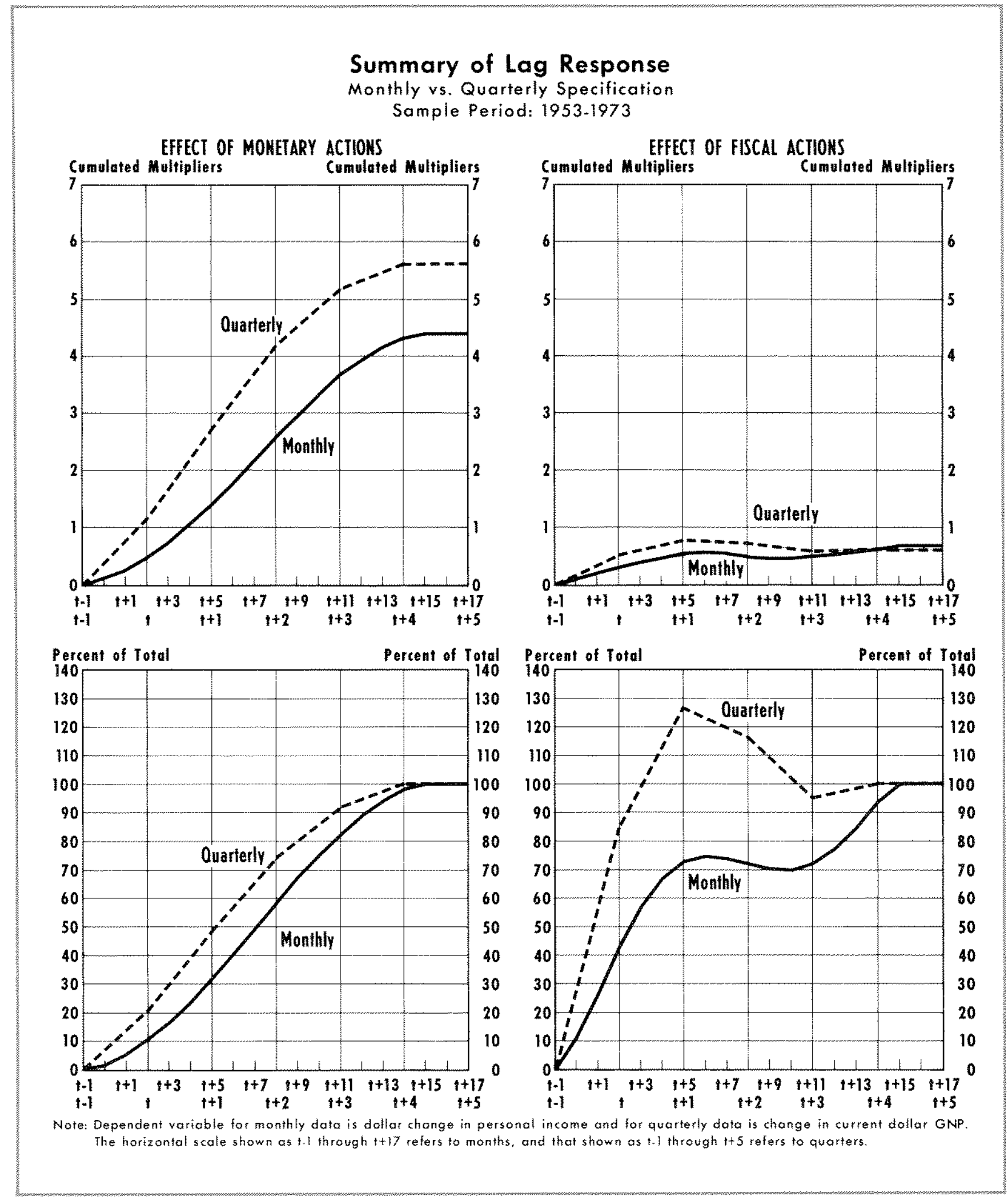

preferred by Andersen and Jordan is used. That specification used money, narrowly defined as demand deposits and currency held by the public, as the measure of the monetary variable, and high-employment Federal expenditures as the measure of the fiscal variable. 


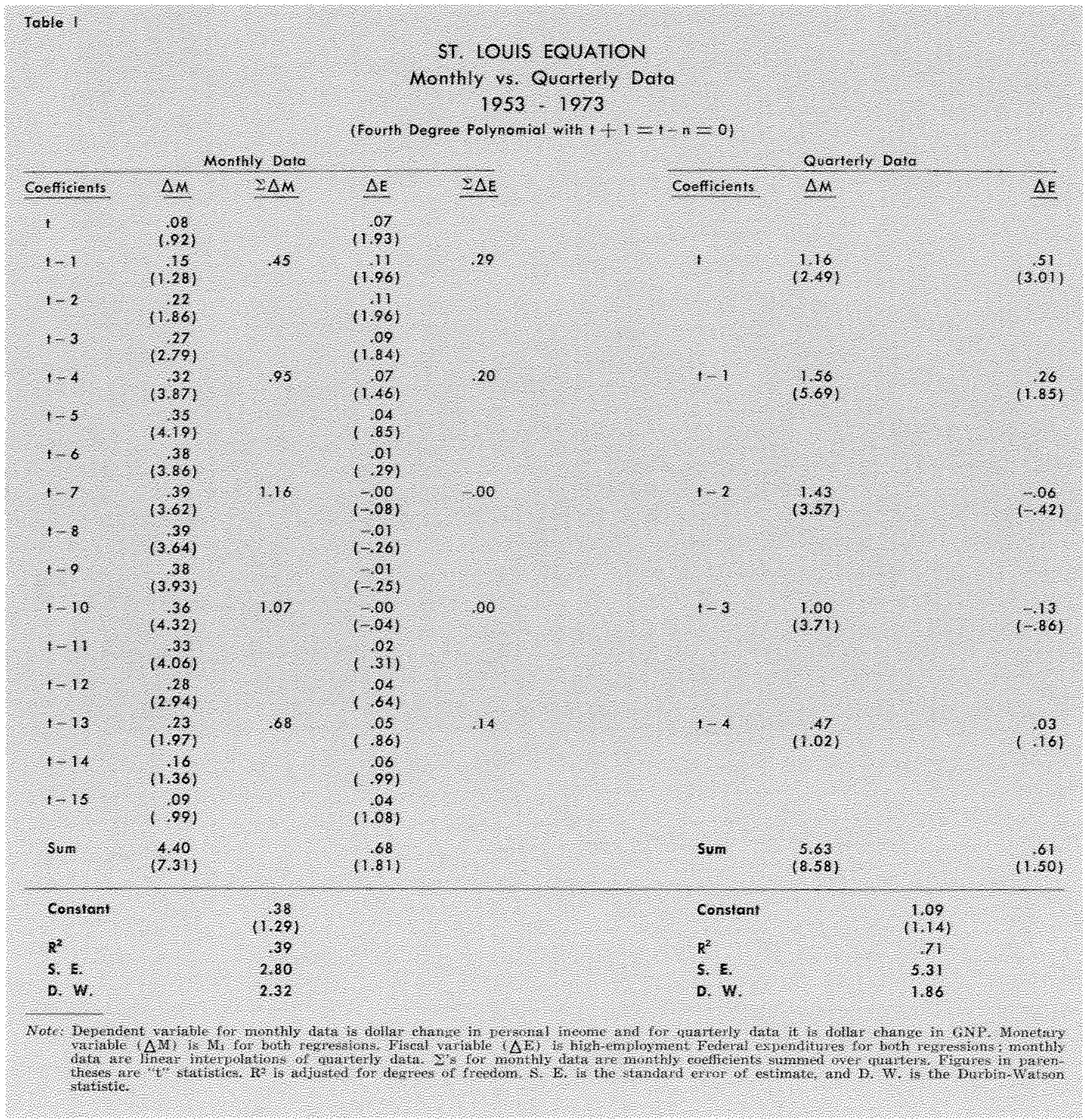

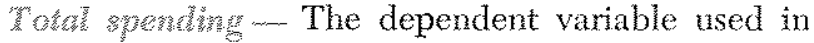
the St. Louis equation is the dollar change in nominal GNP. No similar comprehensive measure is available on a monthly basis. As a proxy for GNP on a monthly basis personal income is used. The rationale underlying this choice is that personal incone is the most comprehensive neasure of aggregate economic activity available on a monthly basis. Over the last twenty years personal income has averaged 79.8 percent of GNP. It should be noted, however, that personal income leaves much to be desired as a monthly proxy for GNP, since it excludes depreciation, indirect business taxes, undistributed corporate profits, and includes transfer payments.

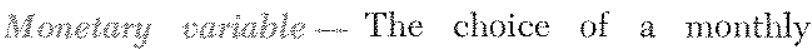
measure of monetary actions is automatic once a particular form of the $S t$. Lonis equation is chosen. The quarterly observations on the money stock narrowly defined are simply the quarterly averages of the 
monthly estimates of the seasonally adjusted noney data.

wask berming - With regard to a monthly measwe of fiscal actions, no such measues are available on a seasonally adjusted basis. Though complex methods of interpolation could probably be developed using the Treasury"s "Monthly Statement of Receipts and Expenditures," the procedure followed here was to interpolate linearly between quarterly estimates of high-employment Federal expenditures. The quarterly observations were assumed to be equal to expenditures for the mid-month of the quarter, and expenditures for the intervening months were calculated by linear interpolation.

\section{Asens}

The estimation proceeded by specifying the same constraints as used by Andersen-Jordan in their study. The equation was estimated with ordinary least squares and the lag structure was estimated by the Almon lag technique. The polynominal was constrained to fourth degree but several lag lengths were examined. In each case the coefficients on the $(t+1)$ and ( $t-n$ ) lags were constrained to zero. The sample period used was 1953 through 1973.

The estimated equations are shown in the accompanying table and a visual summary is given in the accompanying chart. The results for the St. Louis equation estimated with monthly data are compared with the quarterly specification. The $\mathrm{R}^{2}$ and the standard error are lower for the monthly specification, and the Durbin-Watson statistic suggests the presence of negative autocorrelation in the residuals.

Examination of these results indicates that the general quarterly pattern of coefficients on the monetary and fiscal variables is reproduced with the monthly data. The sums of the coefficients for the monetary and fiscal variables are litte different from those for the quarterly model, though there is some indication that the monthly data show a smaller total impact for monetary actions. However, since persomal income is smaller than GNP, the difference in monetary impact can be interpreted as being at tributable to the difference in scale of the dependent variable.
The pattern of lagged response to monetary action, is atso reproduced with the monthly data. The optimal lag length, which was determined by estimating with successively longer lags until the lagged coefficients trailed off into insignificance, appears to be about 16 months which is consistent with 5 quarters when estimated with cuarterly data. That perod, when 50 percent of the monetary impact has occurred, is roughly the same for the two data sets. The guarterly model indicates that almost 50 percent of the impact occurs by the second quater; which conforms with the monthly result indicating one-half of the impact by the eighth month.

The pattern of response to fiscal actions requires additional comment. Since the monthly fiscal variable is a linear interpolation of quarterly observations, reproducing the result of the quarterly model might not seem surprising. ${ }^{8}$ The quarterly version of the St. Louis equation yields a total fiscal multiplier of 0.61 which is not significantly different from zero at the 5 percent level. However, reproduction of these quarterly results for the monthly version comes as a surprise because the dependent variable, personal income, includes transfer payments which are also included in the fiscal variable on the right hand side of the equation. There is some indication of bias though, because scale considerations alone would imply a sum fiscal coeficient for the monthy specification of less than 0.61 .

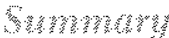

The St. Lotis equation was estimated using monthly data. Using changes in personal income as the dependent variable rather than changes in GNP, the results were consistent with those obtained with quaterly data. Results were presented providing evidence in support of conclusions relating to the magnitude and speed of the impact of monetary and fiscal actions as derived from guartery data. Use of monthly data thus appear to carry the potential for evaluating the thrust of monetary and fiscal actions before quarterly data on GNP beome available.

St should be noted that for the monthly version the " $t$ " statisties for the fiseal variable are probably biased upwart becalse the nimber of independent observations is overstated as a result of interpolation.

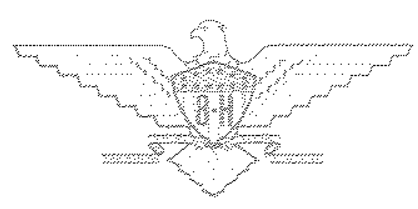

